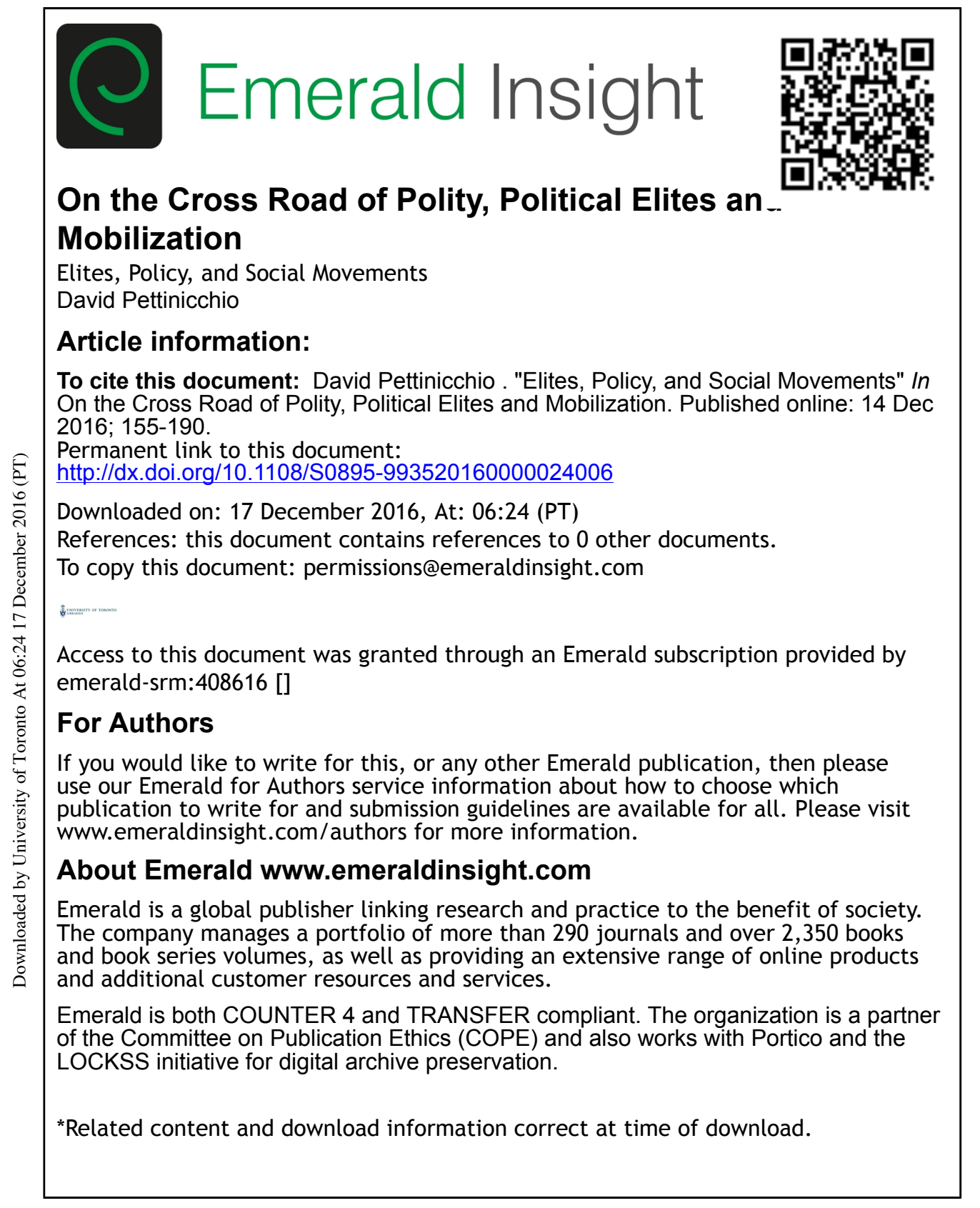




\title{
ELITES, POLICY, AND SOCIAL MOVEMENTS
}

\author{
David Pettinicchio
}

\begin{abstract}
Given the growing interest in social movements as policy agenda setters, this paper investigates the contexts within which movement groups and actors work with political elites to promote their common goals for policy change. In asking how and why so-called outsiders gain access to elites and to the policymaking process, I address several contemporary theoretical and empirical concerns associated with policy change as a social movement goal. I examine the claim that movements use a multipronged, long-term strategy by working with and targeting policymakers and political institutions on the one hand, while shaping public preferences - hearts and minds - on the other; that these efforts are not mutually exclusive. In addition, I look at how social movement organizations and actors are critical in expanding issue conflict outside narrow policy networks, often encouraged to do so by political elites with similar policy objectives. And, I discuss actors' mobility in transitioning from institutional activists to movement and organizational leaders, and even to protesters, and vice versa. The interchangeability of roles among actors promoting social change in strategic action fields points to the
\end{abstract}

On the Cross Road of Polity, Political Elites and Mobilization

Research in Political Sociology, Volume 24, 155-190

Copyright $(\mathcal{C} 2017$ by Emerald Group Publishing Limited

All rights of reproduction in any form reserved

ISSN: 0895-9935/doi:10.1108/S0895-993520160000024006 
porous and fluid boundaries between state and nonstate actors and organizations.

Keywords: Social movements; policy; institutional activists; political entrepreneurs; policy communities; strategic action fields

In a recent exchange with BlackLivesMatter activists, Democratic presidential frontrunner, Hillary Clinton, explained her beliefs about social and political change to activist Julius Jones:

I don't believe you change hearts. I believe you change laws, you change allocation of resources, you change the way systems operate. You're not going to change every heart. You're not. But at the end of the day, we can do a whole lot to change some hearts, and change some systems, and create more opportunities for people who deserve to have them. (http://www.nbcnews.com/news/nbcblk/blacklivesmatter-activists-confrontclinton-incarceration-n411536)

In addition to reflecting a cautious response about social change and activism, as Haberman of the New York Times (August 19, 2015) writes, it also alludes to a particular view of social movements, "that movement politics gets you only so far, and that activists must pave the way for those in office to act." Indeed, Clinton's statement points to several key debates in political sociology including the extent to which social movements matter in shaping policy, the distinction between "insiders" and "outsiders" in promoting political change, whether real policy change occurs incrementally or in punctuated bursts, and whether efforts at changing "hearts and minds" and "changing laws" are distinct (if not opposing) projects.

Social movement scholars have become increasingly interested in the relationship between social movement mobilization and policymaking. Resource mobilization theory provided a framework for understanding social movements as an "extension of institutionalized action" (see Jenkins, 1983; see also McCarthy \& Zald, 1977). Social movement scholars also emphasized the role of political process and political opportunity structures either as control variables (often using some measure of the presence of sympathetic elites, see Meyer \& Minkoff, 2004; Tarrow, 1998) and/or as a mediating variable (e.g., Amenta, 2006; Amenta, Caren, \& Olasky, 2006 on political mediation theory) between mobilization and policy outcomes. 
But, with a growing focus on the direct role of movements in the policymaking process, scholars have had to refine their theoretical and empirical understandings of political institutions and policy elites vis-à-vis social movements in shaping policy. Asking whether social movements matter in shaping policy has led to important advances in situating the work of social movements in the agenda-setting phase of policymaking - that is, where issues are debated and framed (see Amenta, Carens, Chiarello, \& Su, 2010). Social movements are thought to have the most influence in shaping issue discourse in this prepolicy phase and in doing so, indirectly shape policy outcomes.

A second important development involves rethinking the boundaries between state and nonstate, whereby political elites and social movement actors work inside a network or field that transcends institutional boundaries. The growing recognition of the role of institutional activism and political entrepreneurship in promoting movement causes has blurred the distinction between an insider and outsider particularly since actors can easily transition from roles as policymakers to movement activists and vice versa (Banaszak, 2005, 2010; Pettinicchio, 2012, 2013). Specifying the ways in which political elites, social movement organizations (SMOs), and activists routinely interact contributes to our understanding of the networks of incumbents and challengers who coordinate their efforts to shape policy.

Finally, scholars have drawn from the work of institutional and welfare state scholars pointing out that while movements do shape policy outcomes, movements are also shaped by policy (Meyer, 2005). Policies provide both resources and opportunities for SMOs, advocacy groups, and regular citizens to mobilize the law, often targeting (and sometimes solicited by) the very institutions and actors who enacted them (Pettinicchio, 2013).

This paper outlines these and other developments drawing from numerous examples including, among others, the black civil rights movement, the women's movement, the environmental movement, and the disability rights movement. First, I outline a broad framework for situating social movements in the policymaking process. I discuss the conditions under which movements matter in shaping public preferences and/or the policy agenda, as well as how to make sense of short-term and long-term objectives given the protracted interaction between movement groups and policymakers. I then specifically discuss the ways in which so-called outsiders are able to shape the agenda-setting phase of policymaking, especially the kinds of opportunities institutional arrangements and political entrepreneurship create for social movements to have access to the policymaking process. Third, I expand on how policy-domain approaches in agenda setting help specify 
the concept of political opportunities for movements to influence policy. This is followed by a discussion of how strategic action fields shed light on the ways in which social movement actors and political elites work together to affect change through the use of both institutional and extrainstitutional strategies. I point to how distinctions between an "insider" and an "outsider" have consequently become blurred and how movement actors and policymakers move quite fluidly in their roles within this strategic action field. I conclude the paper by addressing the so-called "chicken-and-egg" problem (see Meyer, 2005) regarding how movements are hypothesized to influence policy while policies can also create or undermine opportunities for social movements.

\section{SITUATING SOCIAL MOVEMENTS WITHIN THE POLITICS OF POLICYMAKING}

While social movement scholars on the one hand traditionally viewed challengers working too closely with policymakers and within political institutions as counterproductive to mobilization (Burstein, 1991; Piven \& Cloward, 1977; Tarrow, 1998), policy scholars on the other hand ignored exogenous factors, like the role of social movements, in influencing policy (see Wilson, 2000 on policy regime models).

Social movements are about changing "hearts and minds" as well as policy (Tilly, 1984). Importantly, these should not be seen as two distinct or competing endeavors. In the case of the black civil rights movement, activists sought to raise awareness and shape public attitudes outside the U.S. South hoping that this would pressure political elites to take action, while simultaneously targeting economic and political institutions in the South (McAdam, 1982; Morris, 1984). In the case of gender equality, feminists quickly realized that targeting policy would not necessarily undermine deeply rooted cultural and normative beliefs about gender and gender roles (Taylor \& Whittier, 1995; Van Dyke, Soule, \& Taylor, 2004). Activists therefore targeted political institutions as well as encouraged public questioning of gender norms and gendered structural inequalities. This means that movement targets and objectives range from proximate and short-term to distant and long-term. Thus, social movements have, to use Cockburn's (2007) terminology, a short and long agenda.

Social movements may focus more of their time on shaping hearts and minds than they may on altering structural arrangements. Social movements can target public preferences rather than seeking to change the preferences 
of political elites. This might be because issues are politically closed or simply not on the policy agenda. Other times, when public preferences evolve to coincide with those of a movement, movement activists and organizations may have more leverage in influencing policy change by channeling public preferences towards policymakers. Sometimes, movements may seek to change public opinion and target policy elites concurrently, whereby sympathetic policymakers and social movement activists join forces to mobilize public preferences hoping to affect policy outcomes in their favor.

When the public is divided, or a given issue is not especially salient among constituents, political elites may be more likely to pursue their own policy preferences and/or work with interest and social movement groups aligned with their preferences to shape policy outcomes (Burstein, 2003; Pettinicchio, 2010). In this case, both policymakers and movement representatives benefit. Political elites, interest groups, and SMOs may find it easier to "craft" or frame an issue in the absence of public debate (see Jacobs \& Shapiro, 2000) which in turn, can both direct and intensify issue salience among the public (for instance, see Beckett, 1994 on claimsmaking activity in the "War on Drugs and Crime").

When public issue salience is low, SMOs and interest groups have more control over the message. That is not to say that all groups necessarily have equal access to policymakers. Rather, as Brinton and Francisco (1983) argued in their work on subsystem politics and American policy corporatism, formal organizations are part of an expanding professional advocacy network that is more likely to coordinate with policy elites. They can amplify certain frames while diverting attention away from less favorable ones (Burstein, 2003; Cobb \& Elder, 1983). Pettinicchio (2010) outlined the relationship between elite and public policy preferences in legalizing samesex marriage in Canada. The fact that the Canadian public remained split but uninterested in gay marriage allowed more liberally minded political elites in the Liberal minority government to work with key LGBT and other sympathetic organizations in framing and pursuing marriage equality.

However, public and elite policy preferences may also present a challenge for social movements and interest organizations. Policymakers may be influenced by their own or their party's ideology which may not align with activist and social movement ideology. In a similar vein, public interest and high issue salience can complicate rather than amplify a movement's message especially if public preferences do not coincide with those of a movement or interest group (Burstein, 2003).

The effects of SMOs, interest groups, public preferences and political elites on policy change are therefore contingent on numerous institutional, 
organizational and cultural factors. And, theories about the effects of political organizations on policy outcomes are abound yet, as Burstein and Linton (2002) noted, scholars have either treated the effects of SMO's on policy as taken-for-granted and/or have not adequately outlined how social movements specifically influence policymakers and policies. In his recent volume on advocacy and the U.S. Congress, Burstein (2014) criticized studies that lumped all forms of movement activity into "protest" - especially since some of these activities include lobbying efforts - commonly regarded as an institutional tactic. Additionally, not all SMO tactics have the same effect in shaping elites' policy preferences (see also Gamson, 1975 on organizational success and failure).

Earlier work by Burstein $(1985,1998,1999)$ questioned the direct role of social movement protest in shaping policy outcomes, especially in that protests may have diminishing returns or outright negative effects on policymaking (see also Olzak \& Soule, 2009). Additionally, scholars studying interest and lobby groups pointed out that certain kinds of information information about the size of the constituency and technical policy information - are especially important in influencing policymaking. Yet, others like Agnone (2007) in his work on the environmental movement, showed that protests do matter in changing elite policy preferences. Agnone hypothesized that protests amplify the effects of public preferences on policy by making those preferences more salient to political elites. Importantly, Agnone concluded that specifying the role of social movements in the policymaking process requires situating social movements in the broader institutional and policy context which fluctuates over time.

Thus, the role of social movements in the policymaking process raises questions about short-term and long-term social change processes. Piven and Cloward's $(1971,1977)$ analysis of the poor people's movement and American welfare policy in the 1960s suggested that institutions are inherently stable over long periods of time but for certain points where change comes in bursts. It is here where movements are able to meaningfully affect change. As Costain's (1981, p. 101) work on the women's movement showcased, the ability of movements to shape policy is no small feat given that policymaking tends to proceed incrementally while movements tend to respond in a punctuated manner thus making it difficult for movements to be included in the political process. Tarrow (1993) also described so-called "extraordinary policymaking" pointing to a seemingly rare occurrence when changes in institutions arise as a result of collective action by "outside" challengers.

But, Tarrow went on to claim that sympathetic elites are necessary in translating protest into actual political outcomes - that protest is a 
necessary but insufficient condition for extraordinary policymaking. Indeed, the rise of resource mobilization and political process theories provided the theoretical basis for understanding the routinization of movements. In the "movement society" (Meyer \& Tarrow, 1998), social movements have become increasingly flexible, able to engage in both institutional and extrainstitutional activities. Life cycle perspectives suggest that movements engage in various activities and shift their targets over their life course often as the result of policy and other institutional change (Blumer, 1951; Shultziner, 2013; Tilly, 1978).

As scholars' focus grew to include the ways in which movements influence politics over protracted periods of time, it became increasingly necessary to think about how movements are transformed by political victories and defeats (see for instance, Taylor's, 1989 work on abeyance processes in the women's movement and Haines' (1984) work on radical flank in the civil rights movement). In addition to entering periods of abeyance where movements are more inward focused, movements also endure in large part because they become more "institutionalized." SMOs become increasingly formal and professional (see Staggenborg, 1988). As incumbent groups (Gamson's, 1975), they use more institutional forms of action like lobbying, legal mobilization, and testifying before government hearings.

Professionalization and formalization often occur following policy outcomes that encourage and facilitate the ability of movement actors to work with insiders. But, this does not necessarily mean that institutional tactics come at the expense of extrainstitutional ones. Haines found that in the 1960s, institutionalization of the black civil rights movement led to fractionalization whereby white groups (in the government, private business and philanthropic sectors) increased funding for moderate rights groups as a response to the efforts of radical black organizations - what Haines called a "radical flank effect." Similarly, following Roe v. Wade, informal prochoice groups professionalized, increasingly working with federal policymakers and state legislatures (Staggenborg, 1994). Yet, these SMOs were also quite flexible engaging in both institutional and extrainstitutional activities (see Staggenborg, 1989). And, environmental organizations emerged alongside state institutions like environmental regulatory agencies and bureaus (Johnson, 2008). Nevertheless, the environmental movement's success relied on the efforts of both professionalized and volunteer groups using both institutional and extrainstitutional tactics (Andrews \& Edwards, 2005; see also Andrews \& Edwards, 2004).

Therefore, movements may work with, and benefit from access to, sympathetic elites in an incremental fashion over long periods to shape policy outcomes. Working to affect (and subsequently implement and enforce) 
policy requires continued organizational access to the political process as well as recurring interaction with sympathetic elites. For example, legal mobilization and lobbying efforts by the NAACP in the 1940s and 1950s shaped rights discourse and eventually allowed for activists to pressure the government to act on civil rights legislation (McAdam, 1982). In the case of disability rights, movement activists formed close ties with disability rights political entrepreneurs throughout the 1970s and 1980s especially given that key movement figures had at some point, occupied positions in the government where they learned about, and participated in, the creation of rights-based legislation (see Pettinicchio, 2013; Scotch, 2001).

Numerous other examples highlight the importance of movement interaction with elites over time in influencing policy, as well as how policy influences movement mobilization. Gupta's (2009) analysis of the antideath penalty movement pointed to incremental policy outcomes not only as ends, but also as important factors shaping future movement trajectories. Incremental changes in European sexual harassment policies allowed for political innovations as well as space for outsiders to participate in the policymaking process (Zippel, 2006). Peng and Wong's (2008) discussion of the development of the welfare state in Asia highlighted the ways in which social movements played a critical role in the evolution of political institutions and policy over a sustained period of time.

In addressing how movements matter in the policymaking process, it is crucial to outline the ways in which movements gain access to political elites and the political process, as well as describe how prolonged interaction with political elites takes shape and the consequences this has on social change. There is growing consensus in the social movements and public policy literatures that SMOs and social movement activists have the most influence on policymaking when they participate in the hearings phase of the process - that is, where information about proposed policies and issues are presented, and where actors seek to frame problems and solutions in particular ways to advance a certain policy agenda.

\section{"PRE-POLICY": SETTING THE AGENDA}

One need only turn to the recent Benghazi controversy as an especially salient example of how political elites - political entrepreneurs seeking to change the course of politics ${ }^{1}-$ use congressional committees and the hearing process in their claimsmaking activity. The Benghazi hearings 
played an important role in shaping both elite and public perceptions about key political actors in the current administration as well as the 2016 Democratic presidential nominee, Hillary Clinton. As Democratic strategist, Donna Brazile, told Anderson Cooper on CNN (October 21, 2015), members of the committee are just "there to make a point."

Thus, committees and hearings matter. Committees are the "nerve ends, and the workshops and laboratories of Congress" (Smith \& Deering, 1990, p. 1), they are about "property rights over public policies" (King, 1997, p. 11). Congressional hearings are where political elites seek to stake claims on and influence policy outcomes. As Burstein and Hirsh (2007, p. 179) described, hearings are "an efficient way to gather information and exert influence" and that "simply holding a hearing on an issue communicates a committee's belief that an issue is important."

Movement scholars studying a range of causes have recently pointed out that social movements tend to matter most in the agenda setting or "pre-policy" 2 phase of policymaking. At this early stage, frame contestation manifests itself in committee hearings where social problems, issues, and policy solutions are defined (Burstein \& Hirsh, 2007; Costain, 1992; Gamson \& Modigliani, 1989; Johnson, 2008; King, Bentele, \& Soule, 2007). Depending on how one defines protest, ${ }^{3}$ social movement scholars see movements as indirectly shaping policy outcomes by creating or expanding policy areas, shaping the network of actors involved in a policy domain, and in turn, shaping political discourse around issues (Sawyers \& Meyer, 1999, p. 190). Scholars claim that movements have a much more difficult time shaping policy at the final stages of the policymaking process (Johnson, Agnone, \& McCarthy, 2010; Olzak \& Soule, 2009) where institutional rules and norms make it largely impossible for outsiders to have a say in the content of legislation.

The hearings phase then provides an important opportunity for outsiders to have input on the framing of problems and policies. As Costain (1981, p. 112) claimed, "the ability of government to design policy responsive to new interests, as well as old, hinges critically on the ease with which new interests seeking change in existing policies gain an initial hearing from government decision-makers." Hearings not only provide spaces for outsiders to have a place at the table given that they are often brought in by elites to testify about an aspect of a proposed policy or issue problem, but hearings also signal that political elites have prioritized and increasingly legitimized an issue, allocating institutional resources to that policy area. This means that an increasing number or intensity of hearings is associated with political opportunities for outsiders to interact with policymakers. 
Based on this premise, Sheingate (2006) used the example of biotechnology issue attention to highlight what he called the "congressional opportunity structure." Akin to the broad concept of political opportunity structure well-known to movement scholars, Sheingate posited that the ways in which actors can introduce new ideas, challenge the status quo, and pressure other actors to pursue a given policy course, is dependent on whether there are opportunities to do so. By opportunity, he meant the informal jurisdictions of government committees - that is, what congressional committees hold hearings on rather than what the congressional rules state is their actual jurisdiction. He found that committees with broad, less concentrated jurisdictions spanning many topics, offers "would-be entrepreneurs [with] greater resources and opportunities to introduce new issues that further stretch the boundaries of committee authority" (Sheingate, 2006, p. 856).

As jurisdictions broaden and issue attention increases, there is mounting conflict around issues driven in part by the fact that political entrepreneurs are engaged in jurisdictional claimsmaking. Scholars suggest that social movement groups and leaders are more likely to be brought into this broadening policy network to help bolster elite claims, or as Schattschneider (1960) argued, to help mobilize bias - to create an impression that community stakeholders have a say in a policy issue when in fact it is largely driven by elite policy preferences. Elites use outsiders to advance policies they prefer (McCarthy \& Zald, 2002).

No doubt, movements can also benefit from this increasing access to the agenda-setting process. But, it is not always clear, given the specific issue or policy domain, whether movements have a role in expanding issue attention - whether hearings are held as a result of outside pressure - or whether political elites hold hearings intending to invite movement actors who they see as allies in helping convince other political elites to pursue certain policy directions (see Walker's, 2014 recent discussion of elites and top-down participation). It may be the case that both occur, where initial access provides movements the ability to beget more attention through positive feedback processes. This seems to largely depend on both the institutional and movement contexts at a given time, and on existing policy in that issue area. For instance, drawing from Taylor's (1989) work on abeyance structures in the women's movement, Sawyers and Meyers (1999) argued that the failure of the women's movement to shape two relevant policy domains - fetal protection and family leave - is in part explained by the movement's exclusion from those policy areas. In other words, the movement failed to influence policy because movement groups and leaders 
were left out of the agenda-setting process. However, Pettinicchio (2013) and Scotch (2001) showed that the evolution of disability rights-based discourse in Congress had little to do with outside social movement mobilization. Rather, many who worked closely on rights-based policy in the government would later create disability movement organizations and coordinate protest demonstrations - mobilization around those very laws that established disability rights as a policy area. In many ways, elites created opportunities for social movement groups to participate in subsequent policymaking. It is important to note that groups do not have equal access to elites, and elites will likely seek to coordinate with social movement and interest groups that are ideologically and tactically congruent.

These processes point to a dynamic interplay between elites and social movements in shaping the policy agenda - about why issues sometimes seem ignored, and at other times, seem highly salient. In their two seminal volumes on agenda setting in U.S. Congress, Baumgartner and Jones (1993) and Jones and Baumgartner (2005) claimed that cognitive and institutional limitations on the ability to process information and prioritize issues leads to issues "bursting" onto the policy agenda in a punctuated fashion. Punctuated equilibrium theory - the theory that issues experience periods of stability but occasionally are punctuated with bursts of creative ferment and dramatic expansion - is quite compatible with the notion of cycles of protest or contention whereby movement activity seems to peak at some points, and then declines and remains stable at other points (Tarrow, 1998). Not surprisingly, scholars including Baumgartner and Jones attributed issue attention to social movement activity and changes in public preferences - two so-called "exogenous" and demand-side forces acting on political institutions. Within this framework, social movements have a critical role in expanding conflict around issues. Movement organizations and activists can do so directly by disrupting existing relations within government around certain policy domains. They can also expand conflict indirectly by changing public preferences about issues which in turn signals to policymakers that their voters' preferences about an issue or policy requires action on their part. Under these circumstances, political elites seeking policy change can more easily mobilize conflict and challenge the status quo, especially when structural opportunities, such as venues with broad jurisdictions and interests, present themselves. Sawyers and Meyer (1999) referred to this approach, which emphasizes how networks around particular policy domains change and issues evolve, as an "issue-specific model of political opportunity." 
Outside pressure exerted by social movements does not always play a role in reshaping political discourse or expanding conflict around issues. Take for instance the changing image of nuclear energy. In the 1940s and 1950s, a tight-knit policy network arose around nuclear energy. This meant that a limited number of venues such as the Joint Congressional Committee on Atomic Energy and the Atomic Energy Commission created a small, closed field - a policy monopoly - encompassing government officials, scientists, and public utilities (Baumgartner \& Jones, 1993; Campbell, 1988; Duffy, 1997).

With low issue salience and holding few public hearings, this policy monopoly crafted and controlled the positive image of nuclear energy. But by the end of the $1960 \mathrm{~s}$, the nuclear image turned increasingly negative. Although often attributed to the rise of outside pressures from labor unions, antinuclear, environmental, and anti-war activists, Baumgartner and Jones pointed to pre-existing dissent from within the policy monopoly itself which ultimately signaled its demise. When scientists in the field began to oppose the nuclear industry, it ate away at the legitimacy of the "experts" controlling the nuclear policy monopoly. They sought to move the debate around nuclear energy outside the existing policy subsystem in order to create spaces and opportunities to reframe the issue. New proenvironmental policy initiatives at the end of the 1960s allowed for numerous congressional venues to emerge, as well as new spaces within the executive branch, such as the Environmental Protection Agency (EPA). These endogenous changes to the policy monopoly were eventually bolstered by exogenous changes as a growing focus on environmental regulation and increasing congressional oversight placed much more attention on the issue. Thus, the story of how nuclear energy went from having a tremendously positive image to one that is considerably negative, involved the interplay between both endogenous and exogenous institutional changes as well as challenges from state and local governments, and movement activists who became an increasingly relevant part of the nuclear strategic action field.

One of the shortcomings of theories overemphasizing the role of exogenous and demand-side explanations for how issues and policies evolve is that they ignore the routine access many SMOs enjoy and use to influence change when issues are not seemingly in periods of heightened attention (or "punctuated" to use Baumgartner and Jones' terminology). This is in fact one of the major criticisms put forth by path-dependent scholars regarding models of policy change (Hogan, 2006; Howlett \& Cashore, 2009; 
Pierson, 2003; Streek \& Thelen, 2005). These scholars argued that even though exogenous shocks may lead to bursts of attention, the content of that attention and subsequently, how that content is translated into policy change, reflects the incremental work that preceded punctuation (Deeg, 2001; Rixen \& Viola, 2014). As Streek and Thelen (2005, p. 22) succinctly put it, "for external shocks to bring about fundamental transformations, it helps if endogenous change has prepared the ground."

The movement towards disability rights highlights the importance of incremental changes to existing disability policy which later was able to expand more dramatically in the early-1970s. Throughout the 1950s and 1960s, political elites incrementally proposed changes to an existing policy image of disability couched in service provision - namely, vocational rehabilitation. The evolution of disability policy from economic integration, to removing physical barriers, and guaranteeing equal access to public transit gave rise to a language of rights that was not able to fully materialize until the end of the 1960s. The 1960s reflected an institutional environment undergoing important change - like for instance, the rise of more liberally minded politicians to positions of power (Polsby, 2004). This had important consequences for the broader social welfare policy field that in the past had been blocked from policy innovation. Not surprisingly, the late-1960s and early-1970s saw new political opportunities for disability rights entrepreneurs like Rep. Charles Vanik and Sen. Hubert Humphrey who proposed an amendment to the 1964 Civil Rights Act to include disability as grounds for discrimination. And, although this failed, the language of rights and nondiscrimination survived and became enshrined in the 1973 Rehabilitation Act due to the efforts of disability rights entrepreneurs.

Situating social movements within the policymaking process requires assessing the extent to which changes come about endogenously, how conflict expands outside an existing policy network, how outsiders work to promote conflict and change, and how they do so by working with political elites. The evolution of disability policy came to include civil rights. This took shape inside an existing policy network and when external institutional changes eventually rippled through the disability policy area, it created new opportunities for conflict around the disability policy image to expand, allowing disability policymakers to pursue alternative policy trajectories (such as civil rights). In addition, it showcases the kinds of institutional environments under which state and nonstate actors work closely together to either maintain the status quo or challenge it. 


\section{POLICY COMMUNITIES AND POLITICAL OPPORTUNITIES}

Movement scholars have pointed to the political opportunity structure as one of, if not the, key institutional or set of institutional factors shaping mobilization - from timing, to targets, to tactics. Identifying political opportunities is seen as necessary for understanding the rise of contentious politics. Traditionally, the perspective emphasized conflict between resource-poor outsiders and influential elites (Costain, 1992; Piven \& Cloward, 1977; Tilly, 1978) through the use of "non-institutionalized means" (McAdam, 1982).

Yet, given that the relationship between social movements and the political opportunity structure is inherently "process-oriented" (see Meyer, 2004; Olzak, 1989) - that is, that it takes shape over an extended period of a movement's life course - political process models have in turn provided scholars with a framework for shedding light on routine interactions between challengers and elites, as well as the ways in which elites can facilitate the role of social movement actors in shaping policy outcomes (Carens, 2007; McAdam, McCarthy, \& Zald, 1996; Meyer \& Imig, 1993). Updated versions of the theory then, combined with the rise of resource mobilization theory, came to focus much more on the institutionalized relationship between movements and political elites (see Amenta et al., 2006; Johnson et al., 2010) where cooperation between the two may be just as likely as conflict.

However, the theory has also been heavily critiqued as too broad and as poorly operationalized (Meyer \& Minkoff, 2004; Opp, 2009) leaving many unanswered questions: how are political opportunities identified by activists? Who benefits from these opportunities? And importantly, how do activists benefit from political opportunities? Increasing efforts to link social movements to policymaking through specific mechanisms at both the micro and macro levels have drawn more attention to the shortcomings of political process models and the political opportunity structure. There is a renewed call for a more specific set of institutional and actor-centered factors that facilitate or constrain social movement efforts. The research on agenda setting - particularly policy-domains and policy network approaches (see Dowding, 1995; Knoke, 1993; Knoke \& Laumann, 1982; Marsh \& Rhodes, 1992; Moore, 1979) - offers a useful analytical framework for clarifying the nature of political opportunities for specific social movements, activists, organizations, as well as opportunities associated with specific outcomes, like policy change. 
Although the agenda-setting literature has pointed to institutional arrangements that shape the policy agenda space in general ways, work has also shown that agenda-setting processes vary considerably by issue domain. Factors accounting for variation include: the extent to which policy monopolies or communities exist, the kinds of actors (institutional and movement) involved in the policy area, the extent to which a policy network is embedded in other policy networks, and whether there is elevated public and media issue salience. Baumgartner and Jones, who championed these broad agenda-setting processes, organized their volume around specific cases of agenda setting that fit different patterns of issue attention. For example, in the cases of nuclear power, tobacco, and pesticides, policy monopolies gave way to looser policy networks or policy communities as conflict around these issues emerged. This was not the case, however, for urban disorder, which had no policy monopoly around it. Urban disorder reflected a broad jurisdiction - from public transportation to racial urban unrest - making it difficult to establish distinct issue boundaries around this policy field. Each time this policy area experienced punctuation, citizens and the media were paying a great deal of attention to urban social problems.

In the case of disability, issue expansion was the result of political entrepreneurship. There were no discernable changes in public preferences and issue salience preceding issue expansion. Although disability was governed by a policy monopoly that focused on rehabilitation and other service provision, it had developed extensive ties to social welfare - a burgeoning policy area in the 1960 s - that in part created important institutional opportunities to transform disability policy (Pettinicchio, 2013). Disability issue expansion points to the ways in which policy networks overlap and intersect with other related networks and how changes in the broader field can disorganize existing policy domains.

These cases also reveal that distinct policy networks offer different degrees of access depending on how tightly knit these networks are. Virtually all policy networks extend beyond the government to include nonstate actors from business and industry, the nonprofit sector, and interest and social movement groups. However, policy monopolies, often referred to as "iron triangles," are usually quite closed making it difficult for outsiders and challengers to gain access (Cobb \& Elder, 1983; Kriesi, 2004; Schattschneider, 1960). Policy communities, on the other hand, are a much looser network of actors reflecting a heterogeneous, if not conflicting, set of policy ideas (Baumgartner \& Jones, 1993). Sometimes, newer issues, particularly issues that touch on a myriad of related topics (like urban 
social problems), emerge with no policy subsystem governing them. Alternatively, and often as a result of institutional disruption, existing monopolies too can fall apart allowing for a looser network of actors to form new policy communities around issues. This is important for understanding social movements' access to the policymaking process because the more disorganized an issue area, the more likely challengers can help shape its reorganization (DiMaggio, 1991; McAdam, Tarrow, \& Tilly, 2001). For instance, McCarthy's (2005) study of antidrug issue coalitions demonstrated how coalitions mobilized both elite and public support to challenge existing public health policy. Unlike iron triangles, membership in the coalitions was loosely defined, allowing members including movement organizations, community groups, professionals, and political elites, to come in and out of mobilizing efforts. McCarthy referred to these coalitions as "Velcro triangles" precisely because actors and organizations entered and exited this advocacy coalition with relative ease.

\section{STRATEGIC ACTION FIELDS: HOW SMOS AND POLITICAL ENTREPRENEURS CHANGE POLICY TOGETHER}

Policy fields or networks form as a result of the coordination, cooperation (sometimes reluctantly), and coalition building by strategic actors seeking to shape the policy agenda (Henry, 2011; Knoke, 1993). Policy communities persist when incumbents institutionalize a field by creating norms and assign values to the efforts of its actors. This means that elites confer legitimacy to certain kinds of organizations, structures and policy frames, and delegitimize others. Outsiders also confer a policy network's legitimacy as they acknowledge the expertise of elites (see Brym, 1980 on elite theory, experts and political change). Challenges to the policy community in turn become less likely.

Policy networks and communities are, in Fligstein and McAdam's (2012) terms, strategic action fields where socially skilled actors seek to affect change. Their field theory provides a useful framework for shedding light on the relationship between social movements and policymakers given its emphasis on how policy networks transcend institutional or state boundaries to promote particular policies.

In the United States, policy networks within which political entrepreneurs shape the policy agenda are no doubt grounded in the congressional committees that have some legitimate claim over an issue 
area (Baughman, 2006; King, 1997; Smith \& Deering, 1990). However, scholars, including Fligstein and McAdam, conceived of a broader space within which entrepreneurs and activists work to promote change. These actors - from social movement activists to congressional committee chairs - are "policy actors pursuing a matter of public policy important to them for instrumental reasons" (see Miller \& Demir, 2007, p. 137). Consequently, this understanding helps specify why and how social movement actors and other nonstate actors form ties with political elites because they have similar policy objectives and goals. Policy communities therefore consist of intersecting networks of actors embedded in various organizations and institutions creating a strategic action field where social change takes place.

Members of policy communities influence how issues are defined and in turn, determine policy trajectories. However, as networks that transcend organizational and institutional boundaries (which include nonstate actors), power is not evenly distributed among actors in the community. Power arises from a combination of various sources - from material resources, to status (e.g., the "expert"), to personality and social skill. Additionally, positions within a network also matter. For instance, government actors may have more direct control over policy decisions than nonprofit or interest groups even though all are integral parts of a policy network. Yet, as Dowding (1995) notes, power imbalances within a network cannot be too great if a policy community is to endure given that large power imbalances lead to zero-sum gains. Thus, while power can emanate from sources outside a specific policy domain (Knoke \& Laumann, 1982), power is also contextualized in terms of the norms and culture of a policy network of actors with different interests who come together seeking broadly similar objectives.

Political elites bring their expertise (real or perceived) to a specific policy area. To be sure, the influence of elites can be confined to their respective policy domains (see Dahl, 1961; Polsby, 1963). However, they are also embedded in a broader field of elites that transcend area boundaries (for instance, elected officials may sit on multiple related and unrelated congressional committees). Indeed, being situated within different policy networks increases access to information and in turn actors' clout (Knoke, 1993; Moore, 1979; Sabatier \& Jenkins-Smith, 1999). Field theory explicitly acknowledges that subfields draw from broader fields within which political elites are embedded. That is, civil rights, disability, education, national security, and agriculture do not, as subgovernments, exist in a vacuum. Policy communities therefore reflect aspects of the broader field including 
norms and values, as well as long-standing social cleavages and conflicts. Nonetheless, individual policy communities also consist of their own emergent norms particular to their network and, as Knoke (1993) highlighted, extant political conflicts and divisions may be set aside by actors working to achieve similar goals in a policy area.

For instance, the field of racial politics in the South which transcended economic, cultural, and political lines, was left largely unchallenged by outside actors including the federal government. It enabled the institutionalization of segregation in the South even though relevant actors and groups were themselves embedded in a national American racial field outside the South. Eventually, as Fligstein and McAdam argued, this existing field of racial politics dominated by Jim Crow, Dixiecrats, and other white Southern elites, was disrupted by exogenous shocks; the depression, presidential support for civil rights (i.e., Truman in 1946), and the Supreme Court case, Brown v. Board of Education. These changes in the field of racial politics created an opportunity for contentious politics with the rise of the civil rights movement in the 1950s. As a result of important policy and legislative victories after 1964, as well as broader changes outside the civil rights field (including changes in Cold War era politics, the "revenge" of the Dixiecrats, and the rise of Americas rights revolution in the late-1960s and early-1970s, see Skrentny, 2002), the civil rights field recrystallized around the policy goal of ending overt and covert forms of segregation and discrimination with key incumbents in the executive branch and the courts interpreting and enforcing new legislative victories.

Both Fligstein and McAdam and Baumgartner and Jones agree that exogenous shocks reshape the network of actors - the field - involved in a policy issue. In periods of field disorganization, political entrepreneurs seek to reshape policy images by using their skill to convince others that their policy solutions are the most obvious and suitable. Entrepreneurs can you use their positions of power, resources, personality, "expertise," and scientific evidence and personal narratives to make an issue that was once seen as contentious as taken-for-granted (Birkland, 2007; Carmines \& Stimson, 1989; Cobb \& Elder, 1983; Riker, 1982; Roa, Morrill, \& Zald, 2000; Schattschneider, 1935). This also means that individuals have varying levels of influence on policy given their backgrounds and status within policy networks.

In seeking to redefine issues and policies following disruptions to strategic action fields, hearings again become an important site of frame contestation that bring together political elites, social movement actors, and other relevant parties. Hearings act as important filters where policy initiatives are directly shaped. Hearings played a critical role in reshaping the 
positive image around nuclear power into a negative one, and hearings helped set the environmental agenda when it came to the shift from conservationism to pollution, clean air, and the destruction of the ozone layer. Committees and hearings, as well as the interests of political entrepreneurs, provide social movement groups with opportunities for "input and review" and as a result, "grievances are channeled into institutionalized means of participation” (Rochon \& Mazmanian, 1993, p. 78).

The evolution of disability as a policy issue provides a particularly cogent example of the ways in which the reconfiguration of policy networks created opportunities for issue expansion as well as new access points for SMOs and interest organizations. Disability always had a place on the policy agenda. Policymakers mostly drew from their experience in existing social policy (especially health and education) and expanding interests in veterans' health and social issues to establish a new field of rehabilitation. This came to dominate and indeed, shape disability as a policy area in a path-dependent way by defining a set of policy solutions around integrating people with disabilities into the mainstream of life (i.e., this often meant achieving economic self-sufficiency among people with disabilities).

Throughout the 1940s until the early-1960s, government officials, leaders of incumbent disability groups like the Easter Seals and March of Dimes, and professional health and welfare groups like the Council of State Administrators of Vocational Rehabilitation, formed a close-knit disability policy monopoly revolving around vocational rehabilitation. Not surprisingly, it was here that rehabilitation reached its pinnacle as a policy framework and as an industry, reflecting the professional, ideological, and personal backgrounds of those in this policy monopoly. Many of these policymakers had ties to the health and philanthropic sectors, and many drew from related policy areas adding disability to their policy portfolios.

By the mid-1960s, many working within this area had begun addressing architectural barriers and equal access to public transportation because these were framed as immediately related to vocational rehabilitation. What good is vocational rehabilitation when people with disabilities cannot access places of work? Using strong supporting ideas such as increasing employment opportunities so that people with disabilities can be "tax payers rather than tax burdens," and unquestioned scientific evidence about rehabilitation and special education, policy "experts" (see Altman \& Barnartt, 1993; see also Berkowitz, 1987) were largely uncontested and elites and the public outside this monopoly deferred to their expertise.

The basis for much of rights-based policy began to emerge through incremental changes in the 1960 s by this policy network. However, it was 
not allowed to flourish because disability rights entrepreneurs faced institutional barriers - chief among them, that conservative Southern Democrats blocked most of their efforts deemed too costly. But when Congress liberalized, new opportunities, like the creation of new venues in Congress (for instance, the Subcommittee on the Handicapped among others), became available for an expanding set of actors to pursue various policy areas, including disability rights. This reflected a broader change in the political opportunity structure where an activist government politicized a variety of social issues and existing vocational rehabilitation policies became subsumed in Johnson era Great Society initiatives. It was during this time, as Baumgartner and Jones illustrated with their extensive longitudinal hearings data, that social welfare issues burst onto the policy agenda. In the case of disability, the number of committees holding disability-related hearings expanded and as a result, so did the disability-related agenda space (Pettinicchio, 2013).

The erosion of the client-service policy monopoly created new spaces for political entrepreneurs in both Congress and the executive branch seeking to alter the course of disability policy. It was in this context that Sen. Bob Bartlett proposed the Architectural Barriers Act in 1967, Rep. Mario Biaggi in 1969 proposed an amendment to the Mass Transportation Act such that people with disabilities "have the same right as other persons to utilize mass transportation," and Vanik and Humphrey in 1971 proposed amending the Civil Rights Act to include disability. At the time, the Health, Education and Welfare Department (HEW) had greatly expanded its portfolio dealing with an increasing number of constituencies that it, in turn, championed. HEW's Office of Civil Rights played a particularly critical role in generously interpreting and expanding congressional intent on civil rights for people with disabilities, often to the chagrin of top members in the administration. Importantly, these structural changes helped to lift the cognitive barrier among policymakers that disability policy was, as a matter of fact, based exclusively on a client-service model.

Both the movement for black civil rights and disability rights were situated within a broader network of actors in intersecting fields who routinely interacted with each other to produce consensus about the ways in which issues were defined and how policies developed. Both cases also highlight the extent to which "outsiders," including social movement actors, are included in policy networks, highly dependent on the environment within which policy networks themselves are embedded. When a policy monopoly controls a policy domain as was the case with rehabilitation in disability, only incumbent groups might have access to the network and venues in 
government to shape policy. When a policy community emerges around a policy domain - a broader, looser field of actors working in a policy area (see Dowding, 1995; Heclo, 1978) - social movements are more likely to be involved in generating conflict and challenging the policy status quo especially when they side with sympathetic policymakers in those policy domains seeking to undermine it.

The evolution of disability rights showcases how slow and incremental, and faster and more punctuated change, shaped the expansion and the content of the disability policy agenda. It also points to the overlapping policy networks between disability and other social policy issue areas, and how disability policymakers pursued rights legislation in the absence of issue salience among the public or with the media. This alludes to key supply-side variables, like the availability of venues and the entrepreneurial efforts among political elites in shaping policy. But, it also points to the kinds of relationships political elites forge with nascent advocacy organizations and movement leaders forming a strategic action field whose members sought to expand conflict when institutional activism was not enough to overcome political hurdles.

\section{INSIDERS, OUTSIDERS, AND INSTITUTIONAL ACTIVISM}

The expansion of the agenda space and the broader and looser network of political actors who stake claims on issues, facilitates the ability of so-called outsiders, like SMOs, to influence policymaking. As Stearns and Almeida (2004) suggested, movements often form strong ties with political elites which helps the movement gain legitimacy while movements can help promote the interests of government actors and agencies from the outside. Indeed, policy entrepreneurs often rely on interest groups and SMOs to participate in agenda setting to help expand their claimsmaking activity. As Pettinicchio (2013, p. 83) claimed, strategic action on the part of entrepreneurs "involves the ability of actors to create consensus around an issue through frame alignment as well as the mobilization of inside and outside actors into a coalition that assists in that effort." This means that entrepreneurial efforts inside institutions can generate opportunities for social movement actors to have a place at the policymaking table. Thus, both movement activists and political elites can be institutional activists when they have the ability to work within, and have access to, institutional resources. 
An institutional activist in the broadest sense is an actor who can affect social change from within institutions - an elite with disproportionate access to political resources (see Khan, 2012 on the "Sociology of Elites"). However, the concept has been used to characterize a variety of different types of elites pursuing social change. Institutional activist has been used synonymously with concepts like sympathetic elites (Tarrow, 1998), political entrepreneur (Reichman \& Canan, 2003; Roa et al., 2000; Skrentny, 2002), elite mobilization (McCarthy, 2005), and inside agitator (Eisenstein, 1996). Because social movements and issue areas reflect varying degrees of outsider status, it in part explains why the term institutional activist has been used so broadly: it reflects dimensions of exclusion vis-à-vis institutions. As Banaszak (2005) claimed, individuals can be legally excluded from the polity as was the case with African Americans in the United States. But, in the case of people with disabilities, they were normatively excluded because it was generally believed that people with disabilities could not advocate on their own behalf. Thus, the role institutional activists play is highly dependent on how much exclusion a movement or constituency experiences.

One important distinction that has emerged is in regards to the overlap between the issues institutional activists promote and social movement causes. Traditionally, institutional activists were thought of as working on pre-existing social movement causes (Pierson, 1994; Santoro \& McGuire, 1997; Tilly, 1978). This might be a result of the legacy of theories like political process that tend to treat political elites as reactionary rather than as proactive. Elites are thought to either accommodate challengers' demands or they increase repression which ultimately signals declining mobilization (Koopmans, 1993; McAdam, 1982; Tarrow, 1998, 1989). Santoro and McGuire (1997) argued that black and feminist policymakers took on the cause of affirmative action inside institutions following heightened periods of movement mobilization and policy change while Staggenborg (1991) pointed to the important role of prochoice policymakers working within legislatures to expand abortion rights.

However, institutional activists can be much more entrepreneurial in working on issues prior to movement mobilization than originally conceived (see Pettinicchio, 2012, 2013). For instance, rights and antidiscrimination legislation for people with disabilities was largely the result of a "movement in the government" (Scotch, 2001). In this case, institutional activists were disability rights entrepreneurs; their actions were not motivated by outside pressures from movements or constituents. At the same time, the actions of these policymakers had a profound impact not only in 
politicizing people with disabilities - that is, in helping make people with disabilities citizens entitled to rights - but also provided policy tools to mobilize against the government when it began to back-stepping on implementing disability rights legislation. In fact, when the government stalled in writing and publishing disability rights regulations, many in the Office of Civil Rights, dismayed by the delay, encouraged disability activists to protest against Joseph Califano, the HEW secretary.

In addition, many disability rights movement leaders and key actors had important ties to the government. For example, Judy Heumann, who interned in Sen. Harrison Williams' office, also created one of the first disability advocacy and protest groups, Disabled in Action. Jill Robinson, a Community Services Administration (CSA) staff member and intern in the National Center for Law and the Handicapped participated in the HEW protests. Other leaders would go on to become political elites themselves. Lex Frieden, who served as executive director of the National Committee on the Handicapped and who helped draft the Americans with Disabilities Act (ADA) in the late 1980s, was the secretary of the advocacy group American Coalition of Citizens with Disabilities in the mid-1970s. Ed Roberts, considered the father of the Independent Living Movement in the early-1970s became Director of the California Department of Vocational Rehabilitation in 1976. And, Justin Dart, the leader of the Texas Independent Living Movement in the 1970s became member of the Texas Governor's Committee for Persons with Disabilities in the early-80s and was later appointed by President Reagan to the National Committee on the Handicapped. As co-chair of the Congressional Task Force on the Rights and Empowerment of People with Disabilities, Dart also played a critical role in helping draft the ADA.

Political elites and social movement activists formed a strategic action field. Together, they pressured the government to act on disability rights. This showcases the kind of alliances formed between so-called insiders and outsiders in affecting change drawing from both institutional and extrainstitutional resources. Importantly, it also points to the ways in which activists inside and outside the government use both institutional and extrainstitutional tactics and strategies depending on the nature of their challenge, political opportunities, and threats. It is a salient example of the porous boundaries between state and nonstate actors and organizations and the interchangeable role of citizen activist and elite or institutional activist within the field.

Social movement scholars struggle to define the role of movement activists when they work closely with political elites. For instance, Jenkins and Eckert (1986) showed how professionalization and elite patronage in the black civil 
rights movement in part weakened movement challenge. In the women's movement, formal organizations that engaged in lobbying activity were thought to not fit the feminist idea of nonhierarchical organizations; that using institutional tactics legitimizes existing institutional arrangements (Costain, 1981). And, Meyer's (1993) work on the nuclear free movement suggested that institutionalization served to coopt or depoliticize the movement.

However, scholars have increasingly recognized the back-and-forth between the work of institutional activism and grassroots activism. Costain and Majstrovic's (1994) work on the women's movement showed that relationships between outside challenges and insider actions are reciprocating. Similarly, Coy and Hedeen's (2005) work on the mediation movement identified the importance of oscillating between institutional work and work challenging institutions as a way to avoid potential cooptation. Ultimately, what these various cases point to is the important joint role of both insiders and outsiders in affecting policy.

\section{HOW POLICIES MOBILIZE CONSTITUENCIES}

The dominance of political process models in the study of social movements has focused mainly on the extrainstitutional basis of state-movement interaction (Goldstone, 2003; Jenkins \& Klandermans, 1995). However, as the discussion so far illustrates, movements often have prolonged, routinized and indeed, institutionalized interactions with policymakers. In addition to the important role of entrepreneurship and institutional activism in creating opportunities for social movements in policymaking, an often-overlooked process is how policies create social movements. Referring back to Meyer's (2005) discussion of social movements and policy, there is a "chicken-andegg" relationship between the work of policy insiders and the efforts of challengers. In earlier work, Sawyers and Meyer (1999) posited that policies are not always an outcome of social movements but rather, policies reflect a dimension of the political opportunity structure. That is, policies can generate mobilization.

Costain's (1992) Inviting Women's Rebellion explained how Congress acted as an initiator on women's issues. The amount of attention Congress paid to women's issues increased following President Kennedy's creation of the President's Commission on the Status of Women (Rupp \& Taylor, 1987). As Costain (1992, pp. 20-21) noted, "The shift from a friendly but somewhat ambiguous relationship between government and women in the fifties to 
unalloyed support at the federal level in the sixties seems promising as an explanation for the timing of the women's movement." The 1970s saw both a proliferation of women's advocacy groups as well as an increase in both insider and outsider activity (Costain, 1992; Minkoff, 1995; Soule, McAdam, McCarthy, \& Su, 1999) which coincided with increasing government attention to women's rights (such as the Equal Rights Amendments, the right to choose, etc.). Congressional interest peaked in the early-to-mid-1970s surrounding the ERA amendments (Soule et al., 1999). Although interest eventually declined, women's issues continued to have a place on the policy agenda.

Similarly, following the Clean Air Act Amendments and the establishment of the EPA, congressional issue attention on the environment increased. It also coincided with the rise of large professional environmental advocacy groups and a spike in protest activity (Olzak \& Soule, 2009). As Johnson (2008, p. 3) noted, "The year 1970 marked the beginning of an environmental era in American public policy."

Policies can mobilize activists to protest because they provide a framework, like new entitlements, on which constituencies can mobilize (Ingram \& Smith, 1993; Reese \& Newcombe, 2003). In the case of disability, few protests took place before the introduction of disability rights and antidiscrimination legislation in 1971. Not only did the early-1970s see the proliferation of disability advocacy organizations, it also saw the emergence of a sustained protest wave that mobilized around the rights enshrined in legislation which was largely the result of political entrepreneurship. By lunging forward on disability rights only to back step when costs of accommodation became a driving force behind growing opposition, the federal government through its policy innovations, "invited a disability rebellion."

These cases reveal that social movements and grassroots activism become important forces in protecting and expanding existing policies. On November 2, 1972, young disability activists organized by the group Disabled in Action, tied up traffic in New York twice that day protesting against President Nixon's vetoing of the Rehabilitation Act. Judy Heumann, Disabled in Action's founder, told reporters that a main goal of the protest, which was a response to threats to an existing policy proposal, was to make "the public aware of the plight of the handicapped." Policy breakthroughs indeed mobilize constituents (Campbell, 2005; Pierson \& Skocpol, 2007; Pratt, 1976; Skocpol, 2007; Walker, 1991). They change the relationship between the government, citizens, and issues where the growth of advocacy organizations, lobbying, protests, and public awareness campaigns in turn reify policy and protect it from retrenchment efforts. Importantly, efforts by elites and movement activists alike target political 
institutions while also seeking to affect public preferences and attitudes about those policies.

\section{DISCUSSION AND CONCLUSION}

Social movements seek to change existing understandings about how to address issues, social problems, and collective grievances. They do so by targeting political elites and institutions, as well as public attitudes. Movements "seek to realize their objectives not only by influencing public policy but also by changing private behaviors, challenging accepted cultural understandings, and transforming the lives of their adherents" (Schlozman, Page, Verba, \& Fiorina, 2005, p. 65). To return to Clinton's comments discussed in the paper's introduction, when movements seek to shape politics and public preferences, they are not necessarily engaged in two countervailing efforts. Rather, as combined efforts in a multipronged and often long-term strategy, working with policy elites can aid in further entrenching policies, and can also work to shape public attitudes which in turn bolsters the legitimacy of movements and policies alike.

Two trends have raised questions about how we know whether social movements matter - in Giugni's (1998) words, whether it was worth the effort. The first is the growing interest in social movements as policy agenda setters. The second is that social movements are increasingly thought of as part of "everyday politics" (Goldstone, 2003; Meyer \& Minkoff, 2004; Pettinicchio, 2012). These shifts in how we view social movements in relation to political institutions, policymakers, and policy outcomes, have important empirical and theoretical consequences. They require thinking more about the ongoing relationship between activists and political elites specifying how so-called outsiders gain access to the policymaking process. Sometimes, movements can pressure elites to be included in the policy process but more often than not, opportunities become available to movements as a result of institutional changes, such as the expansion of venues for claimsmaking, and because political elites seek to form ties with activists to advance their position. Policy-domain approaches provide a useful framework for specifying political opportunities for social movements associated with short-term and long-term outcomes.

There are two main ways in which movements matter for policymaking. The first involves the role of movements in shaping how policies are framed in the prepolicy phase. But, politics often continue following the enactment of legislation. Therefore, the second way social movements matter for 
policy involves protecting policy from potential threats and retrenchment efforts by opponents. This too involves a long-term strategy of policy monitoring to ensure that policies are properly and appropriately implemented and enforced. This in part is what scholars mean when they claim that policies create constituents; that movements mobilize these constituents following policy innovations that further their entrenchment.

If indeed, as Tarrow argued, political elites are necessary for translating protest into policy outcomes, the numerous examples provided in this paper of the kinds of routine access outsiders have to the political process suggest that the influence of movements on setting the agenda may not be as "rare" or "extraordinary" as is generally assumed.

Drawing from current theoretical debates in the study of institutional change and social movement mobilization, I outlined the ways in which consequential policy change can result from the interplay between incremental, endogenous efforts, and punctuated bursts brought on by exogenous shocks. I claimed that social movements are transformed by institutional changes including the collapse of policy monopolies and the rise of looser policy communities that provide movements with certain advantages, including access to the policy process. This sheds some light on how so-called outsiders challenge the status quo and achieve routine access to policymakers: they are often invited to participate in the agenda-setting phase of policymaking and sometimes, encouraged by political entrepreneurs to use extrainstitutional tactics when institutional activism is not enough to overcome political hurdles. As part of a strategic action field, SMOs and actors are critical in expanding the debate outside narrow policy networks. They generate conflict by disrupting existing "cozy" relationships between policymakers, and by raising awareness among the public about alternative policy frames and policy solutions.

When it comes to policymaking, political elites and social movement activists - socially skilled actors - enter into a symbiotic relationship. Political elites rely on challengers to expand the conflict outside of political institutions. At the same time, if the goal of a movement is to influence the policy agenda and policy itself, then there are certain benefits when policymakers confer legitimacy upon movement efforts.

I also pointed to the porous boundaries between state and nonstate actors and organizations. Combined with strategic action fields, the concept of institutional activism highlights actors' mobility in transitioning from a position inside institutions to positions as movement leaders and even protesters, and vice versa. Relatedly, these concepts and theories shed light on the flexibility among social change actors who can use both 
institutional and extrainstitutional resources and strategies together to shape policy outcomes. What the various examples discussed in this paper suggest is that having ties to political elites does not preclude movements from protesting against political institutions.

As social movement scholars and political sociologists increasingly look to synthesizing existing theories to provide a framework for understanding how social movements influence policymaking, we must overcome certain conceptual hurdles and assumptions about insiders and outsiders. The first challenge involves endogeneity. That is, social movements cannot be both part of political institutions and also be affected by these very same political institutions because this would mean that the variables expected to affect an outcome are also a part of that outcome (Pettinicchio, 2012). Blurring the lines between insider and outsider makes these distinctions messy. However, part of the solution to this problem involves clarifying and specifying concepts like political opportunity structure as well as the goals and objectives of social movements. Second, in examining the prolonged interaction between elites and activists, it becomes important to confront the possibility of cooptation - a process whereby authorities manage outsider threats by superficially institutionalizing challengers so that they can maintain the status quo (see Michels, [1911] 1962; Selznick, 1949). Although this can occur, as theories of agenda setting, strategic action fields, and political entrepreneurship suggest, elites can also challenge the status quo, and in doing so, often rely on the efforts of outsiders, like social movements. Finally, we must overcome the negative connotation that has surrounded "institutions" and "institutionalization" including the contrast that is often made between so-called elite theories of democratic policymaking (often associated with terms like "overhead democracy" or "juridical democracy") and pluralism. In seeking to specify the role of social movements in shaping the policy agenda, we must reconcile the idea that elite and movement preferences often coincide, with the more sinister view that when outsiders work too closely with institutions and insiders, they become "imbued with their logic and values" (Tarrow, 1989, 1998).

The paper's broader contribution lies in its goal of helping to "put social movements in their place"; the title of McAdam and Boudet's (2012) recent volume. They referred to two trends that have narrowed the field of social movement inquiry. The first is that the focus of scholars on movement actors and organizations has ignored how other actors, including policymakers and other political elites, also shape social change. Second, the study of social movements has tended to focus on mobilizing efforts or episodes of contention associated with immediate outcomes (usually deemed 
successful in some way). This has led to an overall neglect of the more protracted back-and-forth between movements and elites where outcomes are not immediate. Thus, to borrow from McAdam and Boudet, thinking more about the link between social movements, elites, and policymaking supports a more "Copernican" view of social change efforts, where social movements are not always at the center of the political universe.

\section{NOTES}

1. This is the definition of political entrepreneur provided by Schneider and Teske (1992, p. 737).

2. Edwards, Barrett, and Peake (1997, p. 547) and Smith (2000, p. 80) referred to agenda setting as "pre-policy."

3. Some think of it as strictly disruptive, others count lobbying activities as a form of protest (see Meyer \& Tarrow, 1998; Norris, 2002; Rucht, 2007).

\section{REFERENCES}

Agnone, J. (2007). Amplifying public opinion: The policy impact of the US environmental movement. Social Forces, 85, 1593-1620.

Altman, B., \& Barnartt, S. N. (1993). Moral entrepreneurship and the passage of the ADA. Journal of Disability Policy Studies, 4, 21-40.

Amenta, E. (2006). When movements matter: The Townsend plan and the rise of social security. Princeton, NJ: Princeton University Press.

Amenta, E., Caren, N., Chiarello, E., \& Su, Y. (2010). The political consequences of social movements. Annual Review of Sociology, 36, 287-307.

Amenta, E., Caren, N., \& Olasky, S. (2006). Age for leisure? Political mediation and the impact of the pension movement on U.S. old-age policy. American Sociological Review, $70,516-538$.

Andrews, K. T., \& Edwards, B. (2004). Advocacy organizations in the U.S. political process. Annual Review of Sociology, 30, 479-506.

Andrews, K. T., \& Edwards, B. (2005). The organizational structure of local environmentalism. Mobilization, 10, 213-234.

Banaszak, L. A. (2005). Inside and outside the state: Movement insider status, tactics, and public policy achievements. In D. S. Meyer, V. Jenness, \& H. Ingram (Eds.), Routing the opposition: Social movements, public policy and democracy. Minneapolis, MN: University of Minnesota Press.

Banaszak, L. A. (2010). The women's movement inside and outside the state. New York, NY: Cambridge University Press.

Baughman, J. (2006). Common ground. Stanford, CA: Stanford University Press.

Baumgartner, F. R., \& Jones, B. D. (1993). Agenda and instability in American politics. Chicago, IL: University of Chicago Press. 
Beckett, K. (1994). Setting the public agenda: 'Street Crime' and drug use in American politics. Social Problems, 41, 425-447.

Berkowitz, E. D. (1987). Disabled policy: America's programs for the handicapped. New York, NY: Cambridge University Press.

Blumer, H. (1951). Collective behavior. In A. M. Lee (Ed.), Principles of sociology (pp. 67-121). New York, NY: Barnes \& Noble.

Birkland, T. A. (2007). Agenda setting in public policy. In F. Fischer, G. J. Miller, \& M. S. Sidney (Eds.), Handbook of public policy analysis: Theory, politics and methods (pp. 63-78). New York, NY: Taylor and Francis.

Brinton, M. H., \& Francisco, R. A. (1983). Subsystem politics and corporatism in the United States. Policy and Politics, 11, 273-293.

Brym, R. (1980). Intellectuals and politics. London: George Allen \& Unwin.

Burstein, P. (1985). Discrimination, jobs, and politics: The struggle for equal employment opportunity in the United States since the new deal. Chicago, IL: Univ. Chicago Press.

Burstein, P. (1991). Policy domains. Annual Review of Sociology, 17, 327-350.

Burstein, P. (1998). Bringing the public back in: Should sociologists consider the impact of public opinion on public policy? Social Forces, 77, 27-62.

Burstein, P. (1999). Social movements and public policy. In M. Giugni, D. McAdam, \& C. Tilly (Eds.), How social movementsmatter (pp. 3-21). Minneapolis, MN: University of Minnesota Press.

Burstein, P. (2003). The impact of public opinion on public policy: A review and an agenda. Political Research Quarterly, 56, 29-40.

Burstein, P. (2014). American public opinion, advocacy and policy in congress: What the public wants and what it gets. New York, NY: Cambridge University Press.

Burstein, P., \& Hirsh, C. E. (2007). Interest organizations, information, and policy innovation in the U.S. congress. Sociological Forum, 22, 174-199.

Burstein, P., \& Linton, A. (2002). The impact of political parties, interest groups, and social movement organizations on public policy: Some recent evidence and theoretical concerns. Social Forces, 81, 381-408.

Campbell, A. L. (2005). How policies make citizens: Senior political activism and the American welfare state. Princeton, NJ: Princeton University Press.

Campbell, J. L. (1988). Collapse of an industry: Nuclear power and the contradictions of U.S. policy. Ithaca, NY: Cornell University Press.

Carens, N. (2007). Political process theory. In G. Ritzer (Ed.), Blackwell encyclopedia of sociology. New York, NY: Blackwell.

Carmines, E. G., \& Stimson, J. A. (1989). Issue evolution: Race and the transformation of American politics. Princeton, NJ: Princeton University Press.

Cobb, R. W., \& Elder, C. D. (1983). Participation in American politics: The dynamics of agenda building (2nd ed.). Baltimore, MD: Johns Hopkins University Press.

Cockburn, C. (2007). From where we stand: War, women's activism and feminist analysis. London: Zed Books.

Costain, A. (1981). Representing women: The transition from social movement to interest group. Western Political Quarterly, 34, 100-115.

Costain, A. N. (1992). Inviting women's rebellion. Baltimore, MD: Johns Hopkins University Press.

Costain, A. N., \& Majstrovic, S. (1994). Congress, social movements and public opinion: Multiple origins of women's rights legislation. Political Research Quarterly, 47, 111-135. 
Coy, P. G., \& Hedeen, T. (2005). A stage model of social movement co-optation: Community mediation in the United States. Sociological Quarterly, 46, 405-435.

Dahl, R. A. (1961). Who governs? Democracy and power in an American city. New Haven, CT: Yale University Press.

Deeg, R. (2001). Institutional change and the uses and limits of path dependency: The case of German finance. MPIfG Discussion Paper 01/6 Max Plank Institute for the Study of Societies.

DiMaggio, P. (1991). Constructing an organizational field as a professional project: U.S. art museums, 1920-1940. In W. W. Powell \& P. J. DiMaggio (Eds.), The new institutionalism in organizational analysis (pp. 267-292). Chicago, IL: University of Chicago Press.

Dowding, K. (1995). Model or metaphor? A critical review of the policy networks approach. Political Studies, 43, 136-158.

Duffy, R. (1997). Nuclear politics in America: A history and theory of government regulation. Lawrence, KS: University Press of Kansas.

Edwards, G. C., III, Barrett, A., \& Peake, J. (1997). The legislative impact of divided government. American Journal of Political Science, 41, 545-563.

Eisenstein, H. (1996). Inside agitators. Philadelphia, PA: Temple University Press.

Fligstein, N., \& McAdam, D. (2012). A theory of fields. New York, NY: Oxford University Press.

Gamson, W. (1975). The strategy of social protest. Homewood, IL: Dorsey Press.

Gamson, W., \& Modigliani, A. (1989). Media discourse and public opinion on nuclear power: A constructionist approach. American Journal of Sociology, 95, 1-37.

Giugni, M. (1998). Was it worth the effort? The outcomes and consequences of social movements. Annual Review of Sociology, 98, 371-393.

Goldstone, J. (2003). States, parties and social movements. Cambridge: Cambridge University Press.

Gupta, D. (2009). The power of incremental outcomes: How small victories and defeats affect social movement organizations. Mobilization: An International Quarterly, 14, 417-432.

Haines, H. (1984). Black radicalization and the funding of civil rights: 1957-1970. Social Problems, 32, 31-43.

Heclo, H. (1978). Issue networks and the executive establishment: Government growth in an age of improvement. In A. King (Ed.), The new American political system. Washington, DC: American Enterprise Institute.

Henry, A. D. (2011). Ideology, power, and the structure of policy networks. Policy Studies Journal, 39, 361-383.

Hogan, J. (2006). Remoulding the critical junctures approach. Canadian Journal of Political Science, 39, 657-679.

Howlett, M., \& Cashore, B. (2009). The dependent variable problem in the study of policy change: Understanding policy change as a methodological problem. Journal of Comparative Policy Analysis, 11(1), 33-46.

Ingram, H., \& Smith, S. R. (1993). Public policy for democracy. Washington, DC: Brookings Institution.

Jacobs, L. R., \& Shapiro, R. Y. (2000). Politicians don't pander: Political manipulation and the loss of democratic responsiveness. Chicago, IL: The University of Chicago Press.

Jenkins, C. (1983). Resource mobilization theory and the study of social movements. Annual Review of Sociology, 9, 527-533. 
Jenkins, C., \& Klandermans, B. (1995). The politics of social protest. Minneapolis, MN: University of Minnesota Press.

Jenkins, J. C., \& Eckert, C. M. (1986). Channelling black insurgency: Elite patronage and professional social movement organizations in the development of black movement. American Sociological Review, 51, 812-829.

Johnson, E. (2008). Social movement size, organizational density and the making of federal law. Social Forces, 86, 1-28.

Johnson, E., Agnone, J., \& McCarthy, J. D. (2010). Movement organizations, synergistic tactics, and environmental public policy. Social Forces, 88, 2267-2292.

Jones, B. D., \& Baumgartner, F. R. (2005). The politics of attention. Chicago, IL: University of Chicago Press.

Khan, S. R. (2012). The sociology of elites. Annual Review of Sociology, 38, 361-377.

King, B. G., Bentele, K. G., \& Soule, S. (2007). Protest and policymaking: Explaining fluctuation in congressional attention to rights issues, 1960-1986. Social Forces, 86, 137-163.

King, D. (1997). Turf wars. Chicago, IL: University of Chicago Press.

Knoke, D. (1993). Networks of elite structure and decision making. Sociological Methods \& Research, 22, 23-45.

Knoke, D., \& Laumann, E. O. (1982). The social organization of national policy domains: An exploration of some structural hypotheses. In P. Marsden \& N. Lin (Eds.), Social structure and network analysis (pp. 255-270). Beverly Hills, CA: Sage.

Koopmans, R. (1993). The dynamics of protest waves: West Germany, 1965-1989. American Sociological Review, 58(5), 637-658.

Kriesi, H. (2004). Strategic political communication: mobilizing public opinion in, audience democracies. In F. Esser \& B. Pfetsch (Eds.), Comparing political communication. Theories, cases, and challenges (pp. 184-212). Cambridge: Cambridge University Press.

Marsh, D., \& Rhodes, R. A. W. (Eds.) (1992). Policy networks in British government. Oxford: Clarendon Press.

McAdam, D. (1982). Political process and the development of black insurgency, 1930-1970. Chicago, IL: University of Chicago Press.

McAdam, D., \& Boudet, H. (2012). Putting social movements in their place: Explaining opposition to energy projects in the United States, 2000-2005. Cambridge: Cambridge University Press.

McAdam, D., McCarthy, J. D., \& Zald, M. N. (1996). Introduction: Opportunities, mobilizing structures, and framing processes - toward a synthetic, comparative perspective on social movements. In D. McAdam, J. D. McCarthy, \& M. N. Zald (Eds.), Comparative perspectives on social movements: Political opportunities, mobilizing structures, and cultural framings (pp. 1-20). Cambridge: Cambridge University Press.

McAdam, D., Tarrow, S., \& Tilly, C. (2001). Dynamics of contention. Cambridge: Cambridge University Press.

McCarthy, J., \& Zald, M. N. (2002). The enduring vitality of the resource mobilization theory of social movements. In J. H. Turner (Ed.), Handbook of sociological theory (pp. 533-565). New York, NY: Kluwer Academic/Plenum.

McCarthy, J. D. (2005). Velcro triangles: Elite mobilization of local antidrug issue coalitions. In D. Meyer, V. Jenness, \& H. Ingram (Eds.), Routing the opposition: Social movements, public policy, and democracy (pp. 87-115). Minneapolis, MN: University of Minnesota Press. 
McCarthy, J. D., \& Zald, M. N. (1977). Resource mobilization and social movements: A partial theory. American Journal of Sociology, 82, 1212-1241.

Meyer, D., \& Minkoff, D. (2004). Conceptualizing political opportunities. Social Forces, $82,1457-1492$.

Meyer, D. S. (1993). Institutionalizing dissent: The United States structure of political opportunity and the end of the nuclear freeze movement. Sociological Forum, 8, 157-179.

Meyer, D. S. (2004). Protest and political opportunities. Annual Review of Sociology, $30,125-145$.

Meyer, D. S. (2005). Social movements and public policy: Eggs, chicken and theory. In D. S. Meyer, V. Jenness, \& H. Ingram (Eds.), Routing the opposition. Minneapolis, MN: University of Minnesota Press.

Meyer, D. S., \& Imig, D. R. (1993). Political opportunity and the rise and decline of interest group sectors. Social Science Journal, 30, 253-270.

Meyer, D. S., \& Tarrow, S. (Eds.) (1998). The social movement society: Contentious politics for a new century. Lanham, MD: Rowman \& Littlefield.

Michels, R. ([1911] 1962). Political parties: A sociological study of the oligarchical tendencies of modern democracy. New York, NY: Collier Books.

Miller, H. T., \& Demir, T. (2007). Policy communities. In F. Fischer, G. J. Miller, \& M. S. Sidney (Eds.), Handbook of public policy analysis: Theory, politics and methods (pp. 137-147). New York, NY: Taylor and Francis.

Minkoff, D. (1995). Organizing for equality. New Brunswick, NJ: Rutgers University Press.

Moore, G. (1979). The structure of a national elite network. American Sociological Review, 44, 673-692.

Morris, A. (1984). The origins of the civil rights movement. New York, NY: Free Press.

Norris, P. (2002). Democratic phoenix: Reinventing political activism. New York: Cambridge University Press.

Olzak, S. (1989). Analysis of events in the study of collective action. Annual Review of Sociology, 15, 119-141.

Olzak, S., \& Soule, S. A. (2009). Cross-cutting influences of environmental protest and legislation. Social Forces, 88, 201-225.

Opp, K.-D. (2009). Theories of political protest and social movements. New York, NY: Routledge.

Peng, I., \& Wong, J. (2008). Institutions and institutional purpose: Continuity and change in East Asian social policy. Politics and Society, 36, 61-88.

Pettinicchio, D. (2010). Public and elite policy preferences: Gay marriage in Canada. International Journal of Canadian Studies, 42, 125-153.

Pettinicchio, D. (2012). Institutional activism: Reconsidering the insider/outsider dichotomy. Sociology Compass, 6, 499-510.

Pettinicchio, D. (2013). Strategic action fields and the context of political entrepreneurship: How disability rights became part of the policy agenda. Research in Social Movements, Conflict and Change, 36, 79-106.

Pierson, P. (1994). Dismantling the welfare state? Reagan, thatcher, and the politics of retrenchment. Cambridge: Cambridge University Press.

Pierson, P. (2003). Politics in time: History, institutions, and social analysis. Princeton, NJ: Princeton University Press. 
Pierson, P., \& Skocpol, T. (2007). The rise and reconfiguration of activist government. In P. Pierson \& T. Skocpol (Eds.), The transformation of American politics (pp. 19-38). Princeton, NJ: Princeton University Press.

Piven, F. F., \& Cloward, R. (1977). Poor people's movement. New York, NY: Pantheon.

Piven, F. F., \& Cloward, R. A. (1971). Regulating the poor: The functions of public welfare. New York, NY: Vintage, Random House.

Polsby, N. W. (1963). Community power and political theory. New Haven, CT: Yale University Press.

Polsby, N. W. (2004). How congress evolves: Social bases of institutional change. New York, NY: Oxford University Press.

Pratt, H. J. (1976). The gray lobby. Chicago, IL: University of Chicago Press.

Reese, E., \& Newcombe, G. (2003). Income rights, mothers' rights, or workers' rights? Collective action frames, organizational ideologies, and the American welfare movement. Social Problems, 50, 294-318.

Reichman, N., \& Canan, P. (2003). Ozone entrepreneurs and the building of global coalitions. In C. Humphrey (Ed.), Environment, energy, and society: Exemplary works. Belmont, CA: Wadsworth Publishing.

Riker, W. H. (1982). Liberalism against populism: A confrontation between the theory of democracy and the theory of social choice. Prospect Heights, IL: Waveland Press.

Rixen, T., \& Viola, L. A. (2014). Putting path dependence in its place: Toward a taxonomy of institutional change. Journal of Theoretical Politics, 27, 301-323.

Roa, H., Morrill, C., \& Zald, M. N. (2000). Power plays: How social movements and collective action create new organizational forms. Research in Organizational Behavior, $22,239-282$.

Rochon, T. R., \& Mazmanian, D. A. (1993). Social movements and the policy process. Annals of the American Academy of Political and Social Science, 528, 75-87.

Rucht, D. (2007). The spread of protest politics. In R. J. Dalton \& H.-D. Klingemann (Eds.), The Oxford handbook of political behavior (pp. 708-723). Oxford: Oxford University Press.

Rupp, L. J., \& Taylor, V. (1987). Survival in the doldrums. New York, NY: Oxford University Press.

Sabatier, P. A., \& Jenkins-Smith, H. C. (1999). The advocacy coalition framework: An assessment. In P. A. Sabatier (Ed.), Theories of the policy process (pp. 117-168). Boulder, CO: Westview Press.

Santoro, W. A., \& McGuire, G. M. (1997). Social movement insiders: The impact of institutional activists on affirmative action and comparable worth policies. Social Problems, 44, 503-519.

Sawyers, T. M., \& Meyer, D. S. (1999). Missed opportunities: Social movement abeyance and public policy. Social Problems, 46, 187-206.

Schattschneider, E. E. (1935). Politics, pressures and the tariff: A study of free private enterprise in pressure politics, as shown in the 1929-1930 revision of the tariff. New York, NY: Prentice-Hall.

Schattschneider, E. E. (1960). The semisovereign people: A realist's view of democracy in America. New York, NY: Holt, Rinehart, and Winston.

Schlozman, K. L., Page, B. I., Verba, S., \& Fiorina, M. P. (2005). Inequalities of political voice. In T. Skocpol \& L. R. Jacobs (Eds.), Inequality and American democracy: What 
we know and what we need to learn (pp. 19-87). New York, NY: Russell Sage Foundation.

Schneider, M., \& Teske, P. (1992). Toward a theory of the political entrepreneur: Evidence from local government. American Political Science Review, 86, 737-747.

Scotch, R. (2001). From good will to civil rights. Philadelphia, PA: Temple University Press.

Selznick, P. (1949). TVA and the grassroots. Berkeley, CA: University of California Press.

Sheingate, A. D. (2006). Structure and opportunity: Committee jurisdiction and issue attention in congress. American Journal of Political Science, 50, 844-859.

Shultziner, D. (2013). The socio-psychological origins of the Montgomery bus boycott: Social interaction and humiliation in the emergence of social movements. Mobilization, $18,117-142$.

Skocpol, T. (2007). Government activism and the reorganization of American civic democracy. In P. Pierson \& T. Skocpol (Eds.), The transformation of American politics (pp. 39-67). Princeton, NJ: Princeton University Press.

Skrentny, J. (2002). The minority rights revolution. Cambridge: Harvard University Press.

Smith, M. A. (2000). American business and political power. Chicago, IL: University of Chicago Press.

Smith, S., \& C. Deering. (1990). Committees in Congress. Congressional Quarterly.

Soule, S. A., McAdam, D., McCarthy, J. D., \& Su, Y. (1999). Protest events: Cause or consequence of state action? The U.S. women's movement and federal congressional activities, 1956-1979. Mobilization, 4, 239-255.

Staggenborg, S. (1988). Consequences of professionalization and formalization in the prochoice movement. American Sociological Review, 53, 585-606.

Staggenborg, S. (1989). Stability and innovation in the women's movement. Social Problems, $36,75-92$.

Staggenborg, S. (1991). The pro-choice movement. New York, NY: Oxford University Press.

Stearns, L. B., \& Almeida, P. D. (2004). The formation of state actor-social movement coalitions and favorable policy outcomes. Social Problems, 51, 478-504.

Streek, W., \& Thelen, K. (Eds.) (2005). Beyond continuity: Institutional change in advanced political economies. New York, NY: Oxford University Press.

Tarrow, S. (1989). Democracy and disorder: Protest and politics in Italy 1965-1975. Oxford: Clarendon Press.

Tarrow, S. (1993). Social protest and policy reform may 1968 and the Loi d'orientation in France. Comparative Political Studies, 25, 579-607.

Tarrow, S. (1998). Power in movement. Cambridge: Cambridge University Press.

Taylor, V. (1989). Social movement continuity: The women's movement in abeyance. American Sociological Review, 54, 761-775.

Taylor, V., \& Whittier, N. (1995). Analytical approaches to social movement culture: The culture of the women's movement. In H. Johnston \& B. Klandermans (Eds.), Social movements and culture. London: UCL Press.

Tilly, C. (1978). From mobilization to revolution. New York, NY: Random House.

Tilly, C. (1984). Big structures, large processes, huge comparisons. New York, NY: Russell Sage.

Van Dyke, N., Soule, S. A., \& Taylor, V. A. (2004). The targets of social movements: Beyond a focus on the state. In D. J. Myers \& D. M. Cress (Eds.), Authority in contention (Vol. 25, pp. 27-51). Research in Social Movements, Conflicts and Change. Bingley, UK: Emerald Group Publishing Limited. 
Walker, J. L., Jr. (1991). Mobilizing interest groups in America: Patrons, professions and social movements. Ann Arbor, MI: Michigan University Press.

Walker, E. T. (2014). Grassroots for hire: Public affairs consultants in American democracy. New York, NY: Cambridge University Press.

Wilson, C. A. (2000). Policy regimes and policy change. Journal of Public Policy, 20, 247-274.

Zippel, K. (2006). The politics of sexual harassment: A comparative study of the United States, the European Union and Germany. Cambridge: Cambridge University Press. \#BlackLivesMatter Activists Confront Hillary Clinton on Incarceration. NBC News. Retrieved from http://www.nbcnews.com/news/nbcblk/blacklivesmatter-activists-confront-clinton-incarceration-n411536. Accessed on August 18, 2015. 